\title{
Identyfikacje ideologiczne a preferencje wyborcze społeczeństwa polskiego
}

\author{
The Ideological Identification of the Polish Society and Voting Preferences
}

\section{- Abstrakt •}

Dychotomia lewica-prawica w chwili obecnej trwale porządkuje postrzeganie polityki przez społeczeństwo polskie. Teza ta znajduje liczne potwierdzenia zarówno w dyskursie naukowym, jak i w wynikach badań opinii publicznej. W tym kontekście niezwykle istotny staje się problem ustalenia sposobu rozumienia lewicy i prawicy w odniesieniu do preferencji wyborczych Polaków. Teza oraz hipotezy zweryfikowane zostały za pomocą analizy zmiennych uzyskanych w badaniu własnym prowadzonym w latach 2008-2015 na reprezentatywnej próbie dorosłej ludności Polski. Uzyskane wyniki potwierdzają częściowo prawdziwość stawianej tezy. Zgodność rozumienia dychotomii lewica-prawica z cechami doktrynalnymi jest uzależniona od preferencji wyborczych respondentów, choć nie w przypadku zwolenników wszystkich analizowanych partii. Najbardziej spójne i zgodne z modelem doktrynalnym rozumienie tych pojęć odnaleźć można w elektoracie Sojuszu Lewicy Demokratycznej. W elektoracie Prawa i Sprawiedliwości rozumienie analizowanych pojęć jest niepełne i tylko w części spójne z deklarowaną prawicowością zwolenników tej partii. Największą natomiast dezorientację ideologiczną odnotować należy wśród zwolenników Platformy Obywatelskiej.

\section{- Abstract •}

The current left-right dichotomy permanently organizes the perception of politics by the Polish society. This thesis is confirmed both in academic discourse as well as in the results of public opinion polls. In that context, it becomes extremely important to determine the understanding of the left and the right in relation to the electoral preferences of the Poles. The thesis and the hypotheses were verified in a process of analyzing the variables obtained in the present study, carried out in 2008-2015 on a representative sample of the adults. The results partially confirm the thesis. Compatibility between the understanding the left-right dichotomy and the characteristics of the doctrines depends on the electoral preferences of the respondents, but not for followers of all analyzed batches. The most consistency and compatibility with the model of doctrinal understanding of these concepts can be found in the preferences of the Democratic Left Alliance electorate. In the Law and Justice electorate, the understanding of the analyzed concepts is incomplete and only partially consistent with the declared right wing preferences, whereas, the biggest ideological disorientation can be noted among supporters of the Civic Platform. Undoubtedly, the voters' perception of the po- 
Bez wątpienia jednak postrzeganie przez wyborców polskiej sceny politycznej przez pryzmat podziału lewica-prawica jest nadal skuteczny i aktualny.

Słowa kluczowe: identyfikacje ideologiczne, wybory, lewica, prawica, społeczeństwo polskie litical scene through the lens of the division between the left and the right is still effective and valid.

Keywords: ideological identifications, elections, left, right, Polish society

Dychotomia lewica-prawica obecnie trwale porządkuje postrzeganie polityki przez społeczeństwo polskie. Teza ta znajduje liczne potwierdzenia zarówno w dyskursie naukowym, jak i w wynikach badań opinii publicznej. Jej zwolennicy uzasadniają aktualność opozycji lewicy i prawicy na gruncie trwałych wartości Rewolucji Francuskiej, wokół których w dalszym ciągu toczy się życie polityczne. Wartości te, twierdzą autorzy, w dalszym ciągu generują i określają kształt polityki, wpływają na praktykę społeczną oraz związane z nimi podziały, a także konflikty polityczne (Kitschelt, 1994, s. 9-12). Inni badacze zwracają uwagę na charakter systemowo-funkcjonalny analizowanej dychotomii. Ujmuje on opozycję lewicy i prawicy jako sposób redukcji postrzegania przez ludzi złożoności współczesnego, wielowymiarowego świata polityki, a co za tym idzie - nadawanie sensu zjawiskom politycznym, umożliwiając jednostkom rozumienie tego świata oraz skuteczną komunikację pomiędzy partiami politycznymi a ich elektoratami (Fuchs, 1989; Klingemann, 1989, s. 124). W końcu trzeci zbiór argumentów związany jest z tendencjami uniwersalnymi dotyczącymi funkcjonowania systemu demokratycznego. Zdaniem zwolenników tej linii argumentacyjnej podział na lewicę i prawicę wypływa z samej istoty demokracji, sprzyjającej dualistycznym podziałom wypływającym z większościowego podejmowania decyzji oraz funkcjonowania systemu alternacji władzy w kluczowych instytucjach politycznych (Bobbio, 1996, s. 61-66).

Aktualność opozycji lewicy i prawicy uzasadniają także badania polskiej sceny politycznej. Wskazują one istotne zróżnicowania światopoglądowe pomiędzy ludźmi lewicy a ludźmi prawicy, wyrażające się między innymi w ich stosunku do przeszłości, demokracji i religijności (Grabowska, Szawiel, 2001, s. 143-150). Tezę tę potwierdzają również analizy autoidentyfikacji ideologicznych społeczeństwa polskiego. W badaniach prowadzonych przez autora w latach 2008-2015 ponad $70 \%$ respondentów potrafiło określić własne poglądy i wyznawane przekonania na skali lewica-prawica (tabela 1). 
Tabela 1. Autoidentyfikacje ideologiczne społeczeństwa polskiego (\%)

\begin{tabular}{|c|c|c|c|c|c|c|c|c|}
\hline $\begin{array}{c}\text { rok } \\
\text { badania }\end{array}$ & $\begin{array}{l}\text { skrajna } \\
\text { lewica }\end{array}$ & lewica & centrolewica & centrum & centroprawica & prawica & $\begin{array}{l}\text { skrajna } \\
\text { prawica }\end{array}$ & nie wiem \\
\hline \multirow{2}{*}{2015} & 1,2 & 9,6 & 8,9 & 17,6 & 10,5 & 22,7 & 3,2 & 26,2 \\
\hline & \multicolumn{3}{|c|}{19,7} & 17,6 & \multicolumn{3}{|c|}{36,5} & 26,2 \\
\hline \multirow{2}{*}{2012} & 1,3 & 8,7 & 14,3 & 20,7 & 13,2 & 15,9 & 1,4 & 24,5 \\
\hline & \multicolumn{3}{|c|}{24,3} & 20,7 & \multicolumn{3}{|c|}{30,5} & 24,5 \\
\hline \multirow{2}{*}{2008} & 1,8 & 17,3 & 8,3 & 28,2 & 11,2 & 29,3 & 2,2 & - \\
\hline & \multicolumn{3}{|c|}{27,4} & 29,9 & \multicolumn{3}{|c|}{42,7} & - \\
\hline
\end{tabular}

Źródło: badania własne.

W tym kontekście niezwykle istotnym staje się problem ustalenia sposobu rozumienia lewicy i prawicy w odniesieniu do preferencji wyborczych Polaków. Czy podział ten, jak twierdzą niektórzy autorzy, w wyniku wielowymiarowej i złożonej transformacji systemowej stał się jedynie etykietą, schematycznie porządkującą polską scenę polityczną, lecz pozbawioną głębszych znaczeń i związków z doktryną (Wojtaszczyk, 1995, s. 247), czy może ogranicza rozumienie skomplikowanych i wielowątkowych problemów oraz procesów politycznych (Bobbio, 1996, s. 28-29), a może jednak nadal elektoraty poszczególnych partii politycznych rozumieją i identyfikują te partie na kontinuum lewica-prawica zgodnie $z$ ich doktrynalnym znaczeniem?

\section{Założenia metodologiczne pomiaru identyfikacji ideologicznych}

Tezę oraz hipotezy zweryfikowane zostały za pomocą analizy zmiennych uzyskanych w badaniu własnym prowadzonym w latach 2008-2015 na reprezentatywnej próbie dorosłej ludności Polski. Wykorzystano w nich pytanie wskaźnikowe opracowane i po raz pierwszy zastosowane w 2008 roku. Uzyskane wówczas wyniki stanowią bazę porównawczą, dzięki której możliwe jest nie tylko opisanie profili identyfikacji ideologicznych w kontekście preferencji wyborczych, ale także analiza zmian poglądów, ale również identyfikacji Polaków w perspektywie 7 lat dzielących oba pomiary. W badaniu wykorzystano model empiryczny identyfikacji ideologicznych opracowany i wykorzystany w badaniach własnych przeprowadzonych w 2007 roku (Godlewski, 2008). Wykorzystuje on metodę dyferencjału semantycznego. Umożliwia zbadanie dowolnej liczby par przeciwstawnych poglądów (Mayntz, Holm, Hubner, 1987, s. 67). Aby osiągnąć założone cele, niezbędne było zastosowanie także interwałowej skali pomiaru poglądów badanych. Po- 
sługiwanie się skalą interwałową wymaga standaryzacji i powtarzalności stosowanych jednostek miary. Dzięki temu jednak możliwe jest odtworzenie nie tylko rodzaju poglądów uzależnionych od autoidentyfikacji badanych, lecz także zmierzenie ich kierunku i stopnia natężenia. W badaniu autoidentyfikacji ideologicznych zastosowano skalę Likerta (Frankfurt-Nachmias, Nachmias, 2001, s. 479-481).

Zadaniem respondentów było określenie kierunku i siły własnej identyfikacji testowanych par przeciwstawnych poglądów ideologicznych. W tym celu przedstawiono im 7 par przeciwstawnych poglądów charakteryzujących cechy doktrynalne lewicy i prawicy uporządkowanych w trzy wymiary: 1) ideologiczno-doktrynalny, 2) ustrojowo-gospodarczy oraz 3) społeczny (tabela 2). Następnie dokonano analizy biorąc pod uwagę preferencje wyborcze (deklarowane partie, na które respondenci oddaliby głos) badanych. W analizie uwzględniono elektoraty trzech partii politycznych: Sojuszu Lewicy Demokratycznej, Platformy Obywatelskiej oraz Prawa i Sprawiedliwości ${ }^{1}$.

Tabela 2. Model empiryczny pomiaru identyfikacji ideologicznych społeczeństwa polskiego (\%)

1. Społeczeństwo powinno rewidować swoje poglądy dostosowując je do zmieniającego się świata.

2. Państwo powinno kierować się zasadą rozdziału państwa od kościoła.

3. Najważniejsze sektory gospodarki powinny pozostawać własnością państwa.

4. Wysokość podatków powinna być zróżnicowana w zależności od dochodów obywateli.

5. Państwo powinno w jak najszerszym zakresie prowadzić działalność w sferze socjalnej i społecznej.

6. Związki zawodowe powinny odgrywać dużą rolę w społeczeństwie i państwie.

7. Mniejszości seksualne powinny mieć nieskrępowane prawo wyrażania swoich poglądów i przekonań.
1. Społeczeństwo powinno być wierne tradycyjnym wartościom i poglądom.

2. Państwo powinno przestrzegać wartości chrześcijańskich.

3. Wszystkie sektory gospodarki powinny być prywatną własnością.

4. System podatkowy powinien być ujednolicony niezależnie od osiąganych przez obywateli dochodów (podatek liniowy).

5. Państwo powinno ograniczyć do minimum działalność w sferze socjalnej i społecznej.

6. Rola związków zawodowych powina być ograniczona do minimum w społeczeństwie i państwie.

7. Mniejszości seksualne powinny mieć ograniczone prawo do wyrażania poglądów i przekonań.

Źródło: opracowanie własne.

${ }^{1}$ Ostatnią turę badania prowadzono w styczniu 2015 r. Nie uwzględnia zatem ona zmian preferencji wyborczych, jakie zaszły w społeczeństwie polskim w wyniku wyborów prezydenckich i parlamentarnych. 


\section{Postrzeganie lewicy i prawicy w elektoracie Sojuszu Lewicy Demokratycznej}

Rozumienie pojęć lewica i prawica w elektoracie Sojuszu Lewicy Demokratycznej jest w wysokim stopniu prawidłowe. Średnie ${ }^{2}$ dla wszystkich analizowanych wymiarów oscylują w granicach 1,50 do 2,50 . Świadczy to o trafnym oraz zgodnym z doktrynalnym brzmieniem rozumieniu testowanych poglądów przez zwolenników tej partii. Analizując jednak zmiany identyfikacji w czasie, zauważyć można następujące zjawiska:

- w wymiarze ideologiczno-doktrynalnym dostrzec można dwie tendencje o przeciwstawnych wektorach. $\mathrm{Z}$ jednej strony systematycznie następuje wzrost aprobaty dla tradycyjnie lewicowego postulatu rozdziału państwa od kościoła, z drugiej zaś zaobserwowano odchodzenie od lewicowego poglądu modernizmu światopoglądowego i ideowego w kierunku ideowo prawicowego postulatu tradycjonalizmu w zakresie wartości i wyznawanych poglądów,

- w wymiarze ustrojowo-gospodarczym silną aprobatę dla lewicowego postulatu własności państwa i kontroli kluczowych gałęzi przemysłu oraz systemu podatkowego opartego na podatku progresywnym,

- w wymiarze społecznym stopniowe odchodzenie od lewicowych postulatów istotnej roli związków zawodowych w społeczeństwie i państwie oraz nieskrępowanej wolności, a także prawa wyrażania poglądów, przekonań przez mniejszości seksualne (tabela 3).

Tabela 3. Spolaryzowany profil identyfikacji ideologicznych społeczeństwa polskiego wyborcy Sojuszu Lewicy Demokratycznej

\begin{tabular}{|l|c|c|c|c|}
\hline \multicolumn{1}{|c|}{ Stwierdzenia } & $\mathbf{2 0 1 5}$ & $\mathbf{2 0 1 2}$ & $\mathbf{2 0 0 8}$ & \multicolumn{1}{c|}{ Stwierdzenia } \\
\hline $\begin{array}{l}\text { A. Społeczeństwo powinno } \\
\text { rewidować swoje poglądy } \\
\text { dostosowując je do zmieniającego } \\
\text { się świata. }\end{array}$ & $\mathbf{2 , 1 5}$ & 2,14 & 1,96 & $\begin{array}{l}\text { B. Społeczeństwo powinno być } \\
\text { wierne tradycyjnym wartościom } \\
\text { i poglądom. }\end{array}$ \\
\hline $\begin{array}{l}\text { A. Państwo powinno kierować } \\
\text { sięzasadą rozdziału państwa } \\
\text { i kościoła. }\end{array}$ & $\mathbf{1 , 5 2}$ & 1,75 & 1,86 & $\begin{array}{l}\text { B. Państwo powinno przestrzegać } \\
\text { wartości chrześcijańskich, } \\
\text { katolicyzm powinien być religią } \\
\text { państwową. }\end{array}$ \\
\hline
\end{tabular}

2 Pomiar odbywał się na skali 1 (pełna identyfikacja z poglądem doktrynalnie lewicowym) - 5 (pełna identyfikacja z poglądem doktrynalnie prawicowym). 
Tab. 3 - cd.

\begin{tabular}{|l|l|l|l|l|}
\hline \multicolumn{1}{|c|}{ Stwierdzenia } & $\mathbf{2 0 1 5}$ & $\mathbf{2 0 1 2}$ & $\mathbf{2 0 0 8}$ & \multicolumn{1}{c|}{ Stwierdzenia } \\
\hline $\begin{array}{l}\text { A. Najważniejsze zakłady } \\
\text { przemysłowe powinny pozostawać } \\
\text { własnością państwa. }\end{array}$ & $\mathbf{1 , 8 9}$ & 2,22 & 1,63 & $\begin{array}{l}\text { B. Własność powinna być } \\
\text { wyłącznie prywatna. }\end{array}$ \\
\hline $\begin{array}{l}\text { A. Wysokość podatków powinna } \\
\text { być zróżnicowana w zależności od } \\
\text { dochodów obywateli. }\end{array}$ & $\mathbf{1 , 7 2}$ & 1,94 & 1,89 & $\begin{array}{l}\text { B. System podatkowy powinien } \\
\text { być ujednolicony niezależnie } \\
\text { od osiąganych przez obywateli } \\
\text { dochodów (podatek liniowy). }\end{array}$ \\
\hline $\begin{array}{l}\text { A. Państwo powinno w jak } \\
\text { najszerszym zakresie prowadzić } \\
\text { działalność w sferze socjalnej } \\
\text { i społecznej. }\end{array}$ & $\mathbf{1 , 6 7}$ & 1,81 & 1,70 & $\begin{array}{l}\text { B. Państwo powinno ograniczyć } \\
\text { do minimum działalność w sferze } \\
\text { socjalnej i społecznej. }\end{array}$ \\
\hline $\begin{array}{l}\text { A. Związki zawodowe powinny } \\
\text { odgrywać dużą rolę } \\
\text { w społeczeństwie i państwie. }\end{array}$ & $\mathbf{2 , 4 8}$ & 2,66 & 2,00 & $\begin{array}{l}\text { B. Rola związków zawodowych } \\
\text { powina być ograniczona do } \\
\text { minimum w społeczeństwie } \\
\text { i państwie. }\end{array}$ \\
\hline $\begin{array}{l}\text { A. Mniejszości seksualne powinny } \\
\text { mieć nieskrępowane prawo } \\
\text { wyrażania swoich poglądów } \\
\text { i przekonań. }\end{array}$ & $\mathbf{2 , 4 3}$ & 2,81 & 2,02 & $\begin{array}{l}\text { B. W trosce o dobro społeczne } \\
\text { mniejszości seksualne powinny } \\
\text { mieć ograniczone prawo do } \\
\text { wyrażania poglądów } \\
\text { i przekonań. }\end{array}$ \\
\hline
\end{tabular}

Źródło: badanie własne.

\section{Postrzeganie lewicy i prawicy w elektoracie Platformy Obywatelskiej}

Rozumienie pojęć lewica i prawica w elektoracie Platformy Obywatelskiej jest zamazane, niepełne. Średnie dla wszystkich analizowanych wymiarów oscylują w granicach 2,10 do 3,08, co sytuuje je na pograniczu lewicowości i dezorientacji ideologicznej. Stan ten świadczy o dużym rozmyciu percepcji programu oraz orientacji politycznej partii. Może być to spowodowane konsekwentnie wdrażaną i komunikowaną wyborcom strategią Platformy, która swoją siłę polityczną budowała na relatywnie dużej rozpiętości poglądów - od lewicy do prawicy. Strategia ta, mimo że w krótkiej perspektywie wyborczej skuteczna, w perspektywie dłuższej spowodowała odideologizowanie i pozbawienie tożsamości wyborców tej partii. Analizując zmiany identyfikacji w perspektywie 7 lat, zwrócić należy uwagę na następujące procesy:

- w wymiarze ideologiczno-doktrynalnym zauważyć należy systematyczny zwrot ku doktrynalnie lewicowym postulatom w kwestiach stosunku do zmiany oraz relacji państwo-kościół, 
- w wymiarze ustrojowo-gospodarczym utrzymującą się dezorientację ideologiczną w kwestiach własności oraz modelu podatkowego, choć w tym przypadku zauważyć należy systematyczne przesuwanie się poglądów wyborców tej partii w kierunku lewicowego postulatu progresji podatkowej,

- w wymiarze społecznym rozmycie opinii zarówno w kwestii roli związków zawodowych w państwie, jak i praw mniejszości seksualnych (tabela 4).

Tabela 4. Spolaryzowany profil identyfikacji ideologicznych społeczeństwa polskiego wyborcy Platformy Obywatelskiej

\begin{tabular}{|l|l|l|l|l|}
\hline \multicolumn{1}{|c|}{ Stwierdzenia } & $\mathbf{2 0 1 5}$ & $\mathbf{2 0 1 2}$ & $\mathbf{2 0 0 8}$ & \multicolumn{1}{c|}{ Stwierdzenia } \\
\hline $\begin{array}{l}\text { A. Społeczeństwo powinno } \\
\text { rewidować swoje poglądy } \\
\text { dostosowując je do zmieniającego } \\
\text { się świata. }\end{array}$ & $\mathbf{2 , 4 1}$ & 2,75 & 2,68 & $\begin{array}{l}\text { B. Społeczeństwo powinno być } \\
\text { wierne tradycyjnym wartościom } \\
\text { i poglądom. }\end{array}$ \\
\hline $\begin{array}{l}\text { A. Państwo powinno kierować } \\
\text { sięzasadą rozdziału państwa } \\
\text { i kościoła. }\end{array}$ & $\mathbf{2 , 1 0}$ & 2,09 & 2,49 & $\begin{array}{l}\text { B. Państwo powinno przestrzegać } \\
\text { wartości chrześcijańskich, } \\
\text { katolicyzm powinien być religią } \\
\text { państwową. }\end{array}$ \\
\hline $\begin{array}{l}\text { A. Najważniejsze zakłady } \\
\text { przemysłowe powinny pozostawać } \\
\text { własnością państwa. }\end{array}$ & $\mathbf{2 , 5 9}$ & 2,73 & 2,56 & $\begin{array}{l}\text { B. Własność powinna być } \\
\text { wyłącznie prywatna. }\end{array}$ \\
\hline $\begin{array}{l}\text { A. Wysokość podatków powinna } \\
\text { być zróżnicowana wależności od } \\
\text { dochodów obywateli. }\end{array}$ & $\mathbf{2 , 4 2}$ & 2,44 & 2,54 & $\begin{array}{l}\text { B. System podatkowy powinien } \\
\text { być ujednolicony niezależnie } \\
\text { od osiąganych przez obywateli } \\
\text { dochodów (podatek liniowy). }\end{array}$ \\
\hline $\begin{array}{l}\text { A. Państwo powinno w jak } \\
\text { najszerszym zakresie prowadzić } \\
\text { działalność w sferze socjalnej } \\
\text { i społecznej. }\end{array}$ & $\mathbf{2 , 4 1}$ & 2,56 & 2,50 & $\begin{array}{l}\text { B. Państwo powinno ograniczyć } \\
\text { do minimum działalność w sferze } \\
\text { socjalnej i społecznej. }\end{array}$ \\
\hline $\begin{array}{l}\text { A. Związki zawodowe powinny } \\
\text { odgrywać dużą rolę } \\
\text { w społeczeństwie i państwie. }\end{array}$ & $\mathbf{3 , 0 1}$ & 3,08 & 2,55 & $\begin{array}{l}\text { B. Rola związków zawodowych } \\
\text { powina być ograniczona do } \\
\text { minimum w społeczeństwie } \\
\text { i państwie. }\end{array}$ \\
\hline $\begin{array}{l}\text { A. Mniejszości seksualne powinny } \\
\text { mieć nieskrępowane prawo } \\
\text { wyrażania swoich poglądów } \\
\text { i przekonań. }\end{array}$ & $\mathbf{2 , 8 3}$ & 2,88 & $\begin{array}{l}\text { B. W trosce o dobro społeczne } \\
\text { mniejszości seksualne powinny } \\
\text { mieć ograniczone prawo do } \\
\text { wyrażania poglądów } \\
\text { i przekonań. }\end{array}$ \\
\hline
\end{tabular}

Źródło: badanie własne. 


\section{Postrzeganie lewicy i prawicy w elektoracie Prawa i Sprawiedliwości}

Rozumienie pojęć lewica i prawica w elektoracie Prawa i Sprawiedliwości jest niepełne i tylko w części spójne z deklarowaną prawicowością zwolenników tej partii. Średnie dla analizowanych wymiarów oscylują w granicach 2,01 do 3,86, co sytuuje je na pograniczu dezorientacji ideologicznej i prawicowości. Stan ten odzwierciedla w znaczącym stopniu profil partii - prawicowej w kwestiach doktrynalnych i ustrojowych, natomiast bliższy lewicy w kwestiach gospodarczych i społecznych. Analizując zmiany identyfikacji w czasie, zwrócić należy uwagę na następujące procesy:

- w wymiarze ideologiczno-doktrynalnym zauważyć należy znaczący wzrost aprobaty dla lewicowego postulatu rozdziału relacji państwo-kościół,

- w wymiarze ustrojowo-gospodarczym konsekwentnie pogłębiającą się aprobatę dla lewicowych propozycji utrzymania kontroli państwa nad kluczowymi działami gospodarki oraz modelu zróżnicowania obciążeń podatkowych w zależności od wysokości dochodów obywateli,

- w wymiarze społecznym rozmycie opinii w kwestii roli związków zawodowych w państwie, przy jednoczesnym zwiększeniu się odsetka zwolenników partii opowiadających się za prawicowym postulatem ograniczenia praw mniejszości seksualnych (tabela 5).

Tabela 5. Spolaryzowany profil identyfikacji ideologicznych społeczeństwa polskiego wyborcy Prawa i Sprawiedliwości

\begin{tabular}{|l|l|l|l|l|}
\hline \multicolumn{1}{|c|}{ Stwierdzenia } & $\mathbf{2 0 1 5}$ & $\mathbf{2 0 1 2}$ & $\mathbf{2 0 0 8}$ & \multicolumn{1}{c|}{ Stwierdzenia } \\
\hline $\begin{array}{l}\text { A. Społeczeństwo powinno } \\
\text { rewidować swoje poglądy } \\
\text { dostosowując je do zmieniającego } \\
\text { się świata. }\end{array}$ & $\mathbf{3 , 5 5}$ & 3,84 & 3,31 & $\begin{array}{l}\text { B. Społeczeństwo powinno być } \\
\text { wierne tradycyjnym wartościom } \\
\text { i poglądom. }\end{array}$ \\
\hline $\begin{array}{l}\text { A. Państwo powinno kierować } \\
\text { sięzasadą rozdziału państwa } \\
\text { i kościoła. }\end{array}$ & $\mathbf{3 , 1 1}$ & 3,70 & 3,16 & $\begin{array}{l}\text { B. Państwo powinno przestrzegać } \\
\text { wartości chrześcijańskich, } \\
\text { katolicyzm powinien być religią } \\
\text { państwową. }\end{array}$ \\
\hline $\begin{array}{l}\text { A. Najważniejsze zakłady } \\
\text { przemysłowe powinny pozostawać } \\
\text { własnością państwa. }\end{array}$ & $\mathbf{2 , 1 0}$ & 2,23 & 2,53 & $\begin{array}{l}\text { B. Własność powinna być } \\
\text { wyłącznie prywatna. }\end{array}$ \\
\hline $\begin{array}{l}\text { A. Wysokość podatków powinna } \\
\text { być zróżnicowana w zależności od } \\
\text { dochodów obywateli. }\end{array}$ & $\mathbf{2 , 0 4}$ & 2,05 & 2,45 & $\begin{array}{l}\text { B. System podatkowy powinien } \\
\text { być ujednolicony niezależnie } \\
\text { od osiaganych przez obywateli } \\
\text { dochodów (podatek liniowy). }\end{array}$ \\
\hline
\end{tabular}


Tab. 5 - cd.

\begin{tabular}{|l|c|c|c|l|}
\hline \multicolumn{1}{|c|}{ Stwierdzenia } & $\mathbf{2 0 1 5}$ & $\mathbf{2 0 1 2}$ & $\mathbf{2 0 0 8}$ & \multicolumn{1}{c|}{ Stwierdzenia } \\
\hline $\begin{array}{l}\text { A. Państwo powinno w jak } \\
\text { najszerszym zakresie prowadzić } \\
\text { działalność w sferze socjalnej } \\
\text { i społecznej. }\end{array}$ & $\mathbf{2 , 0 1}$ & 2,20 & 2,53 & $\begin{array}{l}\text { B. Państwo powinno ograniczyć } \\
\text { do minimum działalność w sferze } \\
\text { socjalnej i społecznej. }\end{array}$ \\
\hline $\begin{array}{l}\text { A. Związki zawodowe powinny } \\
\text { odgrywać dużą rolę } \\
\text { w społeczeństwie i państwie. }\end{array}$ & $\mathbf{2 , 3 5}$ & 2,39 & 2,42 & $\begin{array}{l}\text { B. Rola związków zawodowych } \\
\text { powina być ograniczona do } \\
\text { minimum w społeczeństwie } \\
\text { i państwie. }\end{array}$ \\
\hline $\begin{array}{l}\text { A. Mniejszości seksualne powinny } \\
\text { mieć nieskrępowane prawo } \\
\text { wyrażania swoich poglądów } \\
\text { i przekonań. }\end{array}$ & $\mathbf{3 , 8 6}$ & 4,17 & 3,27 & $\begin{array}{l}\text { B. W trosce o dobro społeczne } \\
\text { mniejszości seksualne powinny } \\
\text { mieć ograniczone prawo do } \\
\text { wyrażania poglądów } \\
\text { i przekonań. }\end{array}$ \\
\hline
\end{tabular}

Źródło: badanie własne.

\section{Identyfikacje ideologiczne w grupie osób biernych wyborczo}

Na zakończenie warto poddać analizie identyfikacje osób nieposiadających sprecyzowanych preferencji wyborczych, a co za tym idzie zweryfikować tezę o związku przekonań i wyznawanych poglądów politycznych z uczestnictwem w wyborach. Analiza zgromadzonego materiału empirycznego przeczy tej tezie. Zdecydowana większość (72\%) osób biernych wyborczo ma sprecyzowane poglądy na skali lewica-prawica. Bierność wyborcza występuje zdecydowanie częściej wśród osób o podglądach prawicowych (35\%) niż centrowych lub lewicowych (po 18\% wskazań) - wykres 1. 
Wykres 1. Identyfikacje ideologiczne osób biernych wyborczo

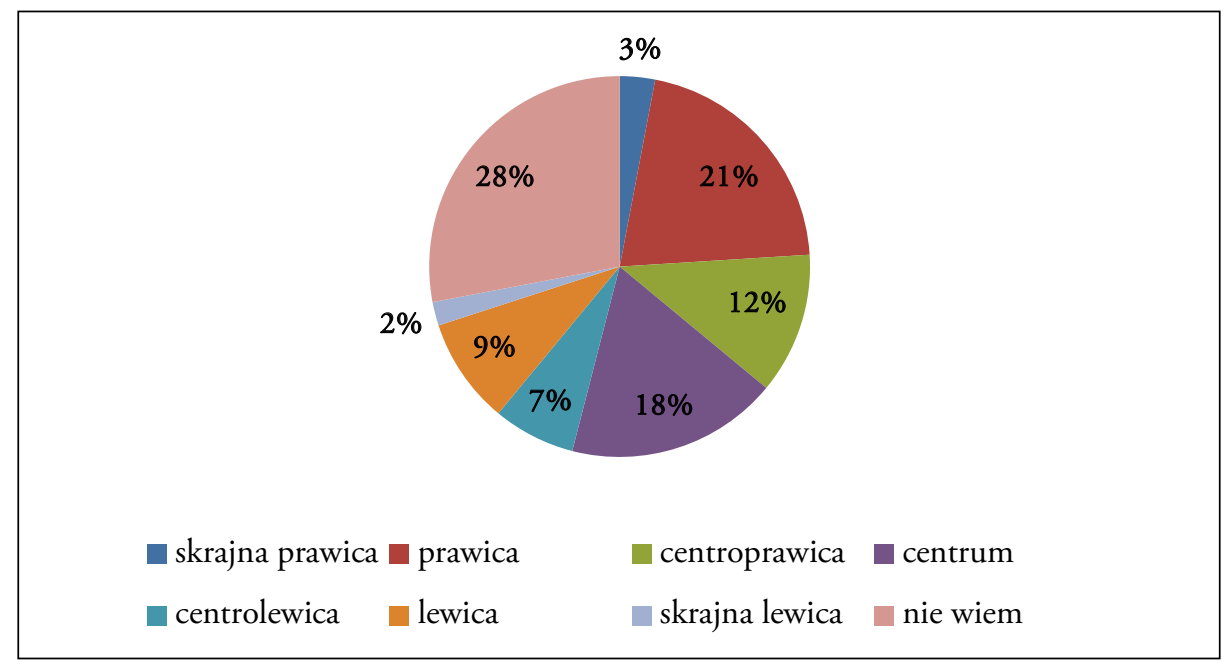

Źródło: badanie własne.

\section{Podsumowanie}

Uzyskane wyniki potwierdzają częściowo prawdziwość stawianej tezy. Zgodność rozumienia dychotomii lewica-prawica z cechami doktrynalnymi jest uzależniona od preferencji wyborczych respondentów, choć nie w przypadku zwolenników wszystkich analizowanych partii. Najbardziej spójne i zgodne z modelem doktrynalnym rozumienie tych pojęć odnaleźć można w elektoracie Sojuszu Lewicy Demokratycznej. W elektoracie Prawa i Sprawiedliwości rozumienie analizowanych pojęć jest niepełne i tylko w części spójne z deklarowaną prawicowością zwolenników tej partii. Największą natomiast dezorientację ideologiczną odnotować należy wśród zwolenników Platformy Obywatelskiej. Negatywnie zweryfikowano natomiast tezę o związku pomiędzy sprecyzowanymi poglądami i preferencjami partyjnymi a aktywnością wyborczą. Zdecydowana większość osób biernych wyborczo ma sprecyzowane poglądy na skali lewica-prawica. Bierność występuje zdecydowanie częściej wśród osób o podglądach prawicowych niż centrowych lub lewicowych.

Bez wątpienia jednak postrzeganie przez wyborców polskiej sceny politycznej przez pryzmat podziału lewica-prawica jest nadal porządkujący, skuteczny i aktualny. 


\section{Bibliografia:}

Bobbio, N. (1996). Prawica i lewica. Kraków: Znak.

Frankfurt-Nachmias, Ch., Nachmias, D. (2001). Metody badawcze w naukach spotecznych. Poznań: Zysk i s-ka.

Fuchs, D., Klingemann, H. D. (1989). The Left-Right Schema. W: W. de Gruyter, Continuities in Political Action. A Longitudinal Study of Political Orientations in Three Western Democraties. Berlin: Walter De Gruyter Inc.

Godlewski, T. (2008). Lewica i Prawica w świadomości społeczeństwa polskiego. Warszawa: Elipsa.

Grabowska, M., Szawiel, T. (2001). Budowanie demokracji. Podziaty społeczne, partie polityczne i społeczeństwo obywatelskie w postkomunistycznej Polsce. Warszawa: PWN.

Kitschelt, H. (1994). The Transformation of European Social Democracy. Cambridge: Cambridge University Press.

Lijphard, A. (1999). Patterns of Democracy. Government Forms and Performance in ThirtySix Countries. New Haven: Yale Universty Press.

Mayntz, R., Holm, K., Hubner, P. (1985). Wprowadzenie do metod socjologii empirycznej. Warszawa: PWN.

Wojtaszczyk, K. (1995). Partie i ugrupowania polityczne. W: R. Chruściak, T. Mołdawa, K. A. Wojtaszczyk, E. Zieliński (red.), Polski system polityczny w okresie transformacji. Warszawa: Elipsa. 